\title{
JUDAISM'S VOICE ON THE RE-EDUCATION OF MAN*
}

The purpose of education is to show that all things belong to God and that all things emanate from Him. When man deviates from this purpose, he descends into the land of Many Opinions where conflict is noisy and not infrequently pursued for selfish ends. The Hebrew prophets-mankind's greatest teachers-prefaced every lesson with the implications of simple things. 'Hast thou entered the springs of the sea?' .... 'Hast thou perceived the breadth of the earth?' ... . 'Who hath begotten the drops of dew?' .... 'Knowest thou the time when the wild goats of the rock bring forth? or canst thou mark when the hinds do calve?

It was questions such as these that silenced Job, brought him to a state of humility, and made him confess: "I uttered that I understood not, things too wonderful for me, which I knew not."

When Job made that confession, he became ready for education. His previous education was a tissue of deceit and useless knowledge and failed him completely when trial and tribulation pressed on him. The background of all true educational endeavour is the ineffable mystery and power of God. This background turns into nonsense the prevailing conflict between "technical" and "classical" education. It weds the two. What makes a plug ignite the gases in an internal-combustion engine, what makes a lettuce form a head, what makes a Shakespeare write a "Hamlet" what makes a Beethoven write a sonata and what makes a swallow fly, are the unanswered questions of engineering, agriculture, literature, music and aeronautics. Their common denominator is mystery: their only answer is God.

Education in our times is, in my view, initially distorted by its silence on the mystery of all things and its fraudulent pretence that it unravels and explains. This is just what it cannot do. Only when a technical college will become as true a sanctuary as a church, and a university as true a place of

"Met vriendelike verlof van „Jewish Affairs”, die amptelike Joodse tydskrif vir Suid-Afrika (waarvoor ons hartlike dank), neem ons hierby onveranderd oor 'n artikel wat in Junie jl. daarin verskyn het van die hand van Henry Katzew. Ons doen dit omdat hierin vir van 'n ons enigsins ongewone kant so sterk die klem gelê word op die religieuse grondslag van alle geestesvorming.-Red. 
insight as a synagogue and a school as true a dwelling of humility as a mosque, will we see the beginnings of a regenerated mankind, a mankind ready to stop playing with bombs.

In this world sliding unwillingly, but not the less certainly, to disaster, many of us are dismayed that Judaism sits muted, passive and imprisoned.

It says nothing or speaks in platitudes. The depths of thought that lie buried in its great seers and the profound spiritual experiences they encompass, it leaves untapped in order to speak in the jargon of the day. It baffles its friends and delights its enemies. The friends speculate at the Silence of a people who once filled the world with their volume of sound; and the enemies rejoice and say: "Here is proof that to the solution of the world's perplexities, Judaism has no contribution to make."

The malaise and the humilation go deeper. For we become challenged to speak; it is demanded of us that we lift our voices. Solitary fighters in the cause of Good pause to ask why we are not at their side; why no lights of thought and guidance penetrate from the power house of Judaism.

Therefore I become greatly daring. I say I will venture to speak. I see men riven and torn by quarrels on the means and ends of education. I see the anger run so deep in Belgium that a capital becomes threatened with siege; I see the holder of aberrant opinion behind the Iron Curtain fall to the hangman; the harshest words expressed in South Africa in recent times are on this subject of education. The hot colas of controversy flare up in discussion on new education ordinances, the Bantu Education Act, and the like. The battle for the soul of youth and man rages everywhere. On no issue is Israel more profoundly split. We Jews here in South Africa are no exceptions. We, too, betray anxiety for our state. For adults we establish a People's College; for our youth we bring out from America a Rabbi Milgrom that we may take counsel with him. We launch a Jewish day school; we proclaim a fund for its development. We announce the goal of the "integrated Jew", though for long many of us remained silent and suspicious of the goal of the "integrated Afrikaner" by methods not dissimilar to our own.

Blame no man and seek no cunning motives. Dilemma and conflict are the natural fruits of any and all concepts of education which belie the truth that education's purpose is to show that all things belong to God and all things emanate from Him.

Let us return to our plug and our lettuce and our Hamlet and our sonata, for we cannot subscribe to the belief that only learned men in black gowns 
may speak to the point on education. There are many books for reading: the book of observation, the book of experience, the book of relationship with fellow men, the book of physical and spiritual quest, the book of aspiration and the books that fall from printing presses. All are valid: they differ only in the degree of their quality. You would have to agree that a sailor who has studied humanity from a ship's fo'c'sle will probably be less ignorant of his subject than a professor who has studied the subject from his scholastic cloister. You would also agree that Moses received more illumination and insight from the burning thorn bush of his conscience than from external study courses. Granting the, this porousness of ours to the floating truths of the universe and particularly, in our case, to the truths chained and anchored by our own Hebrew prophets, what would we say to our sons and daughters of the plug and the lettuce and Hamlet and Becthoven's sonata and the swallow that fies?

We could not go far wrong, by way of introduction, to pass on to them the spirit of wonder captured by the psalmist. "Unto thee, O God, do we give thanks: unto thee, do we give thanks: for that Thy name is near Thy wondrous works declare."

On the plug, then, we would say there were two elements of which we can speak. The first is the mystery of which it is compounded, its root in universal secret, its inexplicable power of ignition. Its origin thus sanctified, known elements borrow the hue of sanctification; and it is in this hue of sanctification that we would range to discuss the heat resistance of plugs, why the firing end of the insulator is tapered, why procelain is used and so on.

You may say this is a strange turn for an article on education to take. But wise men are right to despise the divorce in education of utility from art. The craftsman is essentially religious. Your plug is not only a plug; it is the embodiment of the known and the unknown; and the monotony and boredom of education begin when the known is separated from its unknown and treated in isolation. Thus begins that deceit and distortion in education which made a gentle Emerson utter his sharpest words of rebuke and which sent a Samuel Butler and a Bernard Shaw rocking with laughter.

This truth applies to the lettuce also. You may behold the wonder of a lettuce forming its head and explain it in terms of healthy soil with adequate nitrogen and a sufficiency of trace elements but you would be a fool to leave it at that. Your explanation is still no explanation; and your true education will only begin, as every Hebrew prophet insisted with hammerblow emphasis, when you place the ways of a lettuce alongside the ways of Solomon's serpent on a rock or eagle in the air as beyond the understanding of man. As with 
plug and lettuce so with Shakespeare's Hamlet or a Beethoven sonata. They had their birth in intimations beyond analysis; and it is out of mystery that they impose themselves on the world as forms of higher communication.

This, then, is Judaism's first approach to education; it insists on humility, not dogmatism, from man; and it issues warning in language naked in vigour of the evil that will befall if man struts the world as the "knower". In this sense Judaism is harshly condemnatory of existing approaches to education in Israel, South Africa and elsewhere. It condemns the arrogance of creed, sect and races and all who swell their part-truths into All-Truths. It offers the eternal reminder that all perceptions failed Job until the moment of revelation of man's transience and God's eternity. No approach in education is correct that has not its source in this pool of humility.

This brings us to Judaism's second approach to the education of man.

Judaism is never silent on the harlotry of the senses and is tireless in its insistence that true sight is the sight of the spirit. Thus it abounds in prophetic declamation on eyes that do not see and ears that do not hear, or, more accurately, on eyes that see, yet are blind and ears that are open, yet do not hear.

The proverbs of Solomon offer an example of the vividest imagery in literature on the seductions of the senses and their idols: wealth, esteem, ease, luxury and idleness. These are presented in the shape of the harlot.

Thus the harlot:-

"I have decked my bed with coverings of tapestry, with carved works, with fine linen of Egypt.

"I have perfumed my bed with myrhh, aloes and cinnamon.

"Come, let us take our fill of love until the morning . . . . .

"With her much fair speech she caused him to yield, with the flattering of her lips she forced him.

"He goeth after her straightway, as an ox goeth to the slaughter, or as a fool to the correction of the stocks.

"Till a dart strike through his lover; as a bird hasteth to the snare, and knoweth not that it is for his life .....

Judaism, harsh in its condemnation on any reliance by man on the senses as a key to life, is full of wondrous hope for him who will abandon the senses for reliance on the higher sight of the spirit. This is the sight that inspired Moses to lead the children of Israel out of Egypt, the sight that made it possi- 
ble for Caleb to "unsee" the giant stature of the men of the land of Canaan, the sight that wrung out David's songs of praise, the sight that gave thunder to Isaiah's voice. And the fall of Israel from grace, courage and beauty, is seen by every prophet as due to the rejection of spiritual sight for material sight.

Thus, if there is to be a contribution by Judaism, to the re-education of man, a re-education that has to establish the conditions of man being able to live at peace with himself and his neighbour, it will have to proceed by way of the restoration of spiritual sight to the Jew, and through him as a light to the Gentile. The times are riper for this than we think.

HENRY KATZEW. 